\title{
Clausewitz first, and last, and always: war, strategy and intelligence in the twenty-first century
}

\section{R. Gerald Hughes \& Alexandros Koutsoukis}

To cite this article: R. Gerald Hughes \& Alexandros Koutsoukis (2018): Clausewitz first, and last, and always: war, strategy and intelligence in the twenty-first century, Intelligence and National Security, DOI: $10.1080 / 02684527.2018 .1530867$

To link to this article: https://doi.org/10.1080/02684527.2018.1530867

\section{Published online: 26 Nov 2018.}

Submit your article to this journal $\asymp$

View Crossmark data $\asymp$ 


\title{
Clausewitz first, and last, and always: war, strategy and intelligence in the twenty-first century
}

\author{
R. Gerald Hughes and Alexandros Koutsoukis
}

Christopher Daase and James W. Davis (eds), Introduction by James W. Davis, Clausewitz on Small War (Oxford: Oxford University Press, 2015), pp. viii+252. Hbk. £58. ISBN: 9780198737131.

Christopher Coker, Rebooting Clausewitz: On War in the 21st Century (London: Hurst \& Company, 2017), pp. xiv+188. Pbk. £15.99. ISBN: 9781849047142.

[I]n war more than any other subject we must begin by looking at the nature of the whole; for here more than elsewhere the part and the whole must always be thought of together...l shall not begin by expounding a pedantic, literary definition of war, but go straight to the heart of the matter, to the duel. War is nothing but a duel on a larger scale. Countless duels go to make up war, but a picture of it as a whole can be formed by imagining a pair of wrestlers. Each tries through physical force to compel the other to do his will; his immediate aim is to throw his opponent in order to make him incapable of further resistance.

War is thus an act of force to compel our enemy or opponent to do our will.

Force, to counter opposing force, equips itself with the inventions of art and science. Attached to force are certain self-imposed, imperceptible limitations hardly worth mentioning, known as international law and custom, but they scarcely weaken it. Force - that is, physical force, for moral force has no existence saw as expressed in the state and the law - is thus the means of war, to impose our will on the enemy is its object. To secure that object we must render the enemy powerless; and that, in theory, is the true aim of warfare. That aim takes the place of the object, discarding it as something not actually part of the war itself.

Carl von Clausewitz, Book One: 'On the Nature of War', On War.'

In 2009, US Army General Stanley McChrystal ${ }^{2}$ ordered his chief of intelligence in Afghanistan, one General Michael Flynn, ${ }^{3}$ to assess the situation on the ground there. This came in the wake of a highly critical report by RAND (prepared for the US Joint Forces Command in November 2008) which had embarrassed the newly installed Obama administration by its exposure of glaring failures in US intelligence in Iraq and Afghanistan. In a curious echo of Vietnam, ${ }^{4}$ one anonymous source quoted by the RAND report opined that 'operational commanders...indulge in the fallacy of body counts, and a month in which more Taliban are killed than in the previous month...is actually more likely to reflect the fact that there are more enemy on the battlefield than there were before. ${ }^{5}$ Worse, another source noted that: 'The intelligence on the military side was not tied in with the CIA [Central Intelligence Agency], and the CIA was not listened to... I had my most depressing discussions with the intelligence people who could see what this was leading to'. ${ }^{6}$ The 2009 report subsequently prepared at McChrystal's behest was similarly scathing as Flynn and his two co-authors were unsparing in their excoriation of previous US intelligence efforts in Afghanistan.

[E]ight years into the war in Afghanistan the U.S. intelligence community is only marginally relevant to the overall strategy. Having focused the overwhelming majority of its collection efforts and analytical brain-power on insurgent groups, the vast intelligence apparatus is unable to answer fundamental questions about the environment in which U.S. and allied forces operate. ${ }^{7}$ 
In 2010 Robert Jervis, Adlai E. Stevenson Professor of International Affairs at Columbia University, published a celebrated book about intelligence failure. ${ }^{8}$ While Jervis acknowledged that the US Intelligence Community's (IC) strong point was its ability to convey a great deal of information to policymakers quickly and concisely he, was, nevertheless, struck by 'the bland writing style that often buries the important [points]'. This, Jervis posited, inhibited analysis through opacity. ${ }^{9}$ In essence, both Flynn and Jervis highlighted two central problems: viz. the reduced strategic relevance of the US IC; and exactly how intelligence agencies deal with the inevitable uncertainty in their line of work. Intelligence agencies could do worse than look to the thinking of the Prussian strategist, Carl von Clausewitz (1780-1831). War was famously defined by Clausewitz as 'a continuation of political intercourse, carried on with other means'. ${ }^{10}$ This has become a globally recognized maxim although its variants are legion (Henry Kissinger, for instance, once identified Lenin's approach as turning Clausewitz's argument 'on its head' with politics as a continuation of war by other means). ${ }^{11}$ In the lead-up to the Gulf War of 1991 the strategist Edward Luttwak, a then fellow at the Center for Strategic and International Studies, stated that the Clausewitzian focus on objectives was a crucial strength. 'It's a much more mature consideration of war. Instead of saying what are my resources and how do I best manage them, you say to yourself, what is the nature of the enemy, how do I best cope with him, what happens if I win ' $^{12}$ For Peter Paret, Clausewitz's real strength as a philosopher of war, and the main reason for his endurance as a thinker, lay in his ability to combine 'reality and theory' in such an effective manner. ${ }^{13}$ In 2016 Vanya Eftimova Bellinger, author of a biography of Clausewitz's influential wife, ${ }^{14}$ opined that:

Carl von Clausewitz is known today as the West's most influential military thinker. His seminal treatise On War lies at the heart of modern military doctrine. One recent article even compared its status among U.S. officers to that of St. Paul's letters among Christians.

For generations of readers of On War, Clausewitz, the private man, has been of a bit of mystery. Contemporaries noted that he was reserved and spoke freely and genially in the company of good friends. Although a veteran of many battles and campaigns, Clausewitz often avoided directly citing his own experience in his writings. Only recently his military achievements became the subject of an extensive study, found largely in Donald Stoker's Clausewitz: His Life and Work. ${ }^{15}$

Such endorsements are, however, far from universal and critics of Clausewitz are numerous. Indeed, any number of commentators and scholars who have long since denied that Clausewitz has any relevance today. In this category, notable sceptics of the value of Clausewitzian thought have included notables such as Sir Basil Liddell Hart ${ }^{16}$ (who blamed Clausewitz for the horrors of the First World War ${ }^{17}$ and Sir John Keegan. ${ }^{18}$ Clausewitz has, of course, always had his defenders, as well as his detractors. In 1994, Liddell Hart's deep animosity towards Clausewitz even elicited the following response from Christopher Bassford. 'Rather like Cato the Elder, ending every speech with his famous "Delenda est Carthago," ${ }^{19}$ the British historian, strategist and journalist Basil Liddell Hart (1895-1970) routinely included in his many publications a ringing denunciation of the Prussian military philosopher Carl von Clausewitz.'20 Today, with Clausewitz more widely read than ever, such arguments, often including exchanges littered with sharp attacks and ripostes, show no sign of abating in the near future.

The late Michael Handel, an outstanding scholar of military thought, identified the clear lineage between Sun $\mathrm{Tzu}_{1}{ }^{21} \mathrm{Machiavelli}^{22}{ }^{22} \mathrm{Jomini}^{23}$ and Clausewitz. Handel argued 'that the logic of strategy and waging war is universal rather than parochial, cultural, or regional'. ${ }^{24}$ By the latter part of the nineteenth century what Handel terms a 'classical strategic paradigm for the understanding and direction of war' had emerged out of the works of Sun Tzu, Machiavelli, Clausewitz and Jomini. This new paradigm was summarised by Handel in six points. First, since war serves the political interest, it must always be controlled at the highest level by the political elite - and not the military. Second, war should neither be the first nor the last resort of any given political community. On occasion, it provides the optimum means for advancing the interests of such a community. Third, wars should be fought with clear goals and employ a cost/benefit analysis. Ideally, they 
should thus be won as quickly as possible for the lowest possible material outlay. Fourth, there are limitations on the rationality that can be brought to bear in terms of the analysis of the conduct of wars. Indeed, given factors like emotion and ideology, wars can even be fought rationally for nonrational ends. Fifth, wars cannot be won simply in military terms: political and diplomatic factors must continue to play a role even after the onset of hostilities. Sixth, Handel's paradigm is based upon the observation of human nature and a reading of human history. It is pessimistic, accepting that war can never be abolished (although some wars can be prevented) and that violence is an integral part of the relationships between nations. ${ }^{25}$ And Clausewitz should not be taken either out of context or out of his time. Clausewitz was undoubtedly influenced by the Prussian philosopher Immanuel Kant (1724-1804), famous for his advocacy of peace. Yet it was Kant who, despite having famously written an essay entitled Perpetual Peace: A Philosophical Sketch ${ }^{26}$ - which proposed a peace programme for states everywhere, recognized a 'certain malevolence is rooted in human nature' that was 'quite undisguisedly and irrefutably obvious in the external relation[s] of states to one another'. ${ }^{27}$ Despite this, in the popular mind, it is held that Kant advocated perpetual peace while Clausewitz favoured war-making as the primary rationale of state policy. In truth, while we acknowledge that Kant believed in the possibilities derived from the 'rational agent's ability to cognize and act', ${ }^{28}$ too many of us still conceive of Clausewitz as the 'Mahdi of Mass'.

Far from advocating war, as his detractors have often claimed, what lay at the centre of all of Clausewitz's thinking and writings was a recognition of the inherent link between war and politics. He himself recognized the implications of all of this. And Clausewitz, therefore, wisely cautioned that even military victory is rarely final as the 'defeated state often considers the outcome merely as a transitory evil, for which a remedy may still be found in political conditions at some later date'. ${ }^{29}$ Demonstrating his belief in the indivisibility of war and politics, Clausewitz observed of Sweden's Charles XII (r. 1697-1718): '[he] is not thought of as a great genius, for he could never subordinate his military gifts to superior insights and wisdom, and could never achieve a great goal with them'. ${ }^{30}$ The deficiencies of Charles XII in respect of failing to understand the essential politically nature of war are summed by his declaration to the effect that 'Gentlemen, I have resolved never to start an unjust war but never to end a legitimate one except by defeating my enemies. ${ }^{\text {'31 }}$

Clausewitz first drew a distinction between what he would later term 'limited' and 'absolute' war in 1804. For Clausewitz this meant, respectively, those wars fought to obtain favourable peace terms and those fought with the aim of destroying the enemy's political independence (seine Staatenexistenz aufzuheben). ${ }^{32}$ Napoleon, Clausewitz observed, had a 'plan of operation in wars' that aimed to 'beat the enemy - to shatter him - to drive the enemy into the last corner of the empire - and then, when the confusion was fresh, to dictate a peace'.33 Within this paradigm, the notion of small wars could be assigned to either the 'limited' and 'absolute' category, dependent upon specific circumstances. The nature of contemporary conflict confirms the continued utility of Clausewitz's thinking on small wars. This makes the publication of the first English language version of Clausewitz's lectures on small wars, and other writings on small unit warfare, ${ }^{34}$ particularly timely. In Clausewitz on Small War Christopher Daase and James W. Davis ${ }^{35}$ have translated and edited the most important texts devoted to the analysis of asymmetric, unconventional, guerrilla and small unit warfare. It is clear from reading Clausewitz on Small Wars that, while Clausewitz's reputation as a theorist of classic inter-state conflict is well-deserved, he was also a highly original thinker in the realms of small wars and all forms of asymmetric warfare (including guerrilla warfare and terrorism). ${ }^{36}$ Clausewitz on Small Wars is an important collection and, after an excellent introductory piece by one of the editors, ${ }^{37}$ comprises the following: 'Lectures on Small War, held at the War College in 1810 and $1811^{\prime 38}$; the 'Testimonial (Bekenntnisdenkschrift)' of 1812 (which called for a national war of liberation against Napoleonic France) ${ }^{39}$; 'On the political advantages and disadvantages of the Prussian institution of the Landwehr' from 1819 (an assessment of the effectiveness of the Landwehr, a citizen militia that operated with the Prussian army after having been established on 17 March 1813) ${ }^{40}$ and, finally, 'The arming of the people (Volksbewaffnung)' 
from $1832 .{ }^{41}$ The lectures on small war that comprise the bulk of this collection allow us great insights into the origins of the book Vom kriege as Clausewitz the career soldier turns his attention to recent military developments. Of course, at this time Prussia was a defeated state and an ally of Napoleon, albeit a reluctant one. ${ }^{42}$ In such circumstances, the Prussian War Academy naturally turned to self-reflection and practical military matters (as did the Reichswehr and Hans von Seeckt following Imperial Germany's defeat in 1918). Clausewitz on Small Wars shows Clausewitz at his pragmatic and prescriptive best - seeking to prepare future generations of soldiers to best prepare for the fog and friction of war prior to their being actually engaged in war themselves.

Should anybody doubt whether Clausewitz could tell us any more about small wars, they would be well advised to read Christopher Coker's thoughts on the matter in his new book, Rebooting Clausewitz: On War in the $21^{\text {st }}$ Century. ${ }^{43}$ In Rebooting Clausewitz Coker, a professor at the London School of Economics, weighs into the debates on Clausewitz on all fronts. As a reconsideration of strategic thinking, Rebooting Clausewitz bears all of Coker's familiar stamps. It incorporates, and engages with, the most up-to-date scholarly literature. It is pithily argued - in considerably less than 200 pages - and iconoclastic. Chapter four of Rebooting Clausewitz demonstrates the utility of the approach outlined by Coker in the preceding chapter by means of comparative 'strategy' case studies: viz. 'What went wrong in Iraq and Afghanistan'. Coker's book is far from a straightforward assessment of the much-debated subject of the contemporary relevance of Clausewitz. Coker asserts that, despite his notoriety, the role of politics in Clausewitz's worldview has never been accorded due prominence. ${ }^{44}$ And yet, Clausewitz was unequivocal on the point that it is through political means that wars can be controlled and limited. ${ }^{45}$ He approached, then, what we, roughly speaking, would call the political ideology identified as 'realism' today. ${ }^{46}$ This interpretation of the issue might not be appealing for those of us who remain committed to general moral principles to judge war regardless of place or time. But Clausewitz's central insight about the role of politics in preventing the escalation of conflicts and putting limits to military action might still be very useful. Coker argues that, despite his widespread fame, this role of politics in Clausewitz has not been seriously considered (not even in connection with contemporary conflicts). ${ }^{47}$ That said, Coker is well aware of the mythologies that have grown up around the person of Clausewitz and On War. In one of the more notorious myths, Coker notes that Hitler is often supposed to have been a keen devotee of Clausewitz and his work although we should be 'eternally grateful' that Hitler got the Prussian philosopher of war all wrong. ${ }^{48}$ As a work of deconstructive analysis, Coker's book has two original takes on On War. First, Coker peels the veneer of the Kantian teleological elements from Clausewitz, and transforms him into a Darwinist. This is recognition that war serves a Darwinian function. Coker posits that the relationship between war and Darwinism means that, as Clausewitz predeceased the relevant scientific discoveries, his theory is incomplete. ${ }^{49}$ Second, Coker writes for a broader audience, careful not to exclude those unfamiliar with Clausewitzian ideas (former US Secretary for Defense Donald Rumsfeld, for instance, was supposedly unaware of the concept of the 'centre of gravity'). ${ }^{50}$

In an important recent book Thomas Waldman examined post-Cold War debates over Clausewitz's continued relevance in the face of onslaughts from the 'new war' theorists, proponents of 'non-Trinitarian' warfare', and the technological determinism of the extreme proponents of the Revolution in Military Affairs (RMA). ${ }^{51}$ Waldman argued that anti-Clausewitzians tended to base their case against Clausewitz on popular secondary readings which do inaccurately portray the meaning and utility of the Trinity. Against this, enthusiasts for Clausewitzian thinking have often downplayed the extent of change in warfare since Clausewitz's time, often because of the anachronistic parts of Clausewitz's writings (on cavalry, for example). Waldman asserts that the admirers of Clausewitz need not fret: indeed, the entire theoretical framework of Clausewitz can be readily adapted to rapid and radical change. ${ }^{52}$ In Rebooting Clausewitz, Coker sets about making his (Clausewitzian) case in innovative and refreshing ways. This original approach has Carl von Clausewitz himself dismantling the big fads of today: these include 'new wars', 'big data', and the Revolution in Military Affairs (RMA). In doing this, Coker is seeking to address recent critics of 
Clausewitz in an engaging and lively manner, warning against judging people long in their grave by means of contemporary mores. ${ }^{53}$

Michael Handel's view of the universality of 'the logic of strategy and waging war $^{\prime 54}$ is a widely held view (shared, for instance, by Mao Zedong). ${ }^{55}$ There are, of course, certain constants in the study of war but, as Clausewitz noted, 'every age had its own kind of war, its own limiting conditions, and its own peculiar preconceptions'. ${ }^{56}$ Yet this flexibility has not rendered Clausewitz invulnerable to the charge of his advancing obsolete ideas. The changes wrought in society - that have caused Clausewitzian thought to be superseded - have been seen to lead to what is termed 'new wars' by Mary Kaldor (like Coker hailing from the London School of Economics). This label was deemed to be a response to the transformation wrought in 'organized violence' in the last decades of the twentieth century. ${ }^{57}$ In 2010, Kaldor asserted her belief in the redundancy of certain aspects of Clausewitz's thinking thus:

The notion of absolute war, the inner tendency of war to lead to extremes, which I regard as the core of Clausewitzean theory, is no longer applicable. For Clausewitz, war was fundamentally about the 'urge to decision', which was achieved through fighting, that is to say combat between two warring parties, and this implied the need for speed and concentration; the suspension of belligerent action and the dispersal of forces did, of course, take place but were explained in terms of departures from the inner nature of war. Today's wars, by contrast to the European wars of the 19th and 20th centuries, are inconclusive, long lasting and have a tendency to spread. My argument is that this is because these wars have a different inner nature. In this sense, a Clausewitzean understanding of these wars can be deeply counterproductive in developing appropriate international strategies both for trying to end these wars and for the role of military forces. ${ }^{58}$

Refuting such thinking, James W. Davis asserts that critics of Clausewitz see his work as being limited by virtue of its 'time-bound framework' for analyses. Clausewitz's approach, it is argued, fails to 'anticipate forms of warfare beyond the rather symmetric pitched battlefield exchanges of large regular armies - the "old wars" that are said to have characterized his own times.' Davis argues that much of the criticism is misplaced as commentators often mistakenly attack versions of Clausewitzian thought produced by individuals other than Clausewitz himself. Further, many critics of Clausewitz have been limited to his works available in the English language and relied too heavily on the 'unfinished work On War'. ${ }^{59}$ In 2017 Jack Levy observed of Clausewitz critics Kaldor and Van Creveld:

Some interpret Clausewitz as arguing that war involves the use of state armies as an instrument of state policy and conclude that Clausewitz has little to say about insurgencies, guerrilla war, and other forms of violence by non-state actors. Van Creveld, for example, defines Clausewitz's trinity as 'the people, the army, and the government' and concludes that Clausewitz cannot explain insurgencies or other forms of 'nontrinitarian' warfare. ${ }^{60}$ Similarly, Mary Kaldor claims that 'war, in the Clausewitzean definition, is war between states for a definable political end, i.e., state interest,' and concludes that Clausewitz can explain 'old wars' but not 'new wars. ${ }^{61}$

This interpretation of Clausewitz in strictly statist terms is quite misleading. Although Clausewitz refers to the people, the army and the government, he does so only after first identifying the 'dominant tendencies' of war in the form of the 'remarkable trinity' of primordial violence, chance and the subordination of war to policy. ${ }^{62}$ This trinity is eternal and unchanging across time and space. ${ }^{63}$

Even Kaldor does, however, acknowledge the continued value of certain portions of Clausewitz's thinking. And she acknowledges that Clausewitz's influence is such, that 'new wars' can 'only be defined in contrast to what went before and our understanding of what went before depends heavily on what we learn from reading [Clausewitz's] On War'. ${ }^{64}$ Coker's book involves the application of Clausewitzian ideas to the contemporary world by integration of such concepts as 'big data' ${ }^{65}$ into the great Prussian thinker's worldview. Coker constructs three fictional scenarios. First, Clausewitz is placed in a seminar at the United States Military Academy (USMA) at West Point (where he asserted that his work is 'Kantian') ${ }^{66}$; second, he debates the course of post-2001 'War on Terror' at an imaginary think-tank in Washington DC; and, third, participates in a lively seminar on the Hegelian-type debate on the utility of reading history. ${ }^{67}$ This third exchange is situated at a meeting of the Military History Circle in London. These three essays locate Clausewitz across the 
centuries, deconstruct and analyse his philosophy of war. Coker is not offering a hagiography of Clausewitz. Instead, he argues that the advances in evolutionary psychology and neuroscience made since Clausewitz's death in 1831, vindicate and even expand Clausewitz's view of war. What is clear is that, even though he was unaware of them, Clausewitz's theories have proved remarkably resilient in the face of the major technological developments that have occurred since his death. This is an important and novel argument that Coker advances in crystalline fashion, having developed his thinking through a series of publications that include the books, Can War Be Eliminated? and Future War. ${ }^{68}$

Coker's work is part of the latest wave of a renaissance in Clausewitzian studies; his accessible style will make Clausewitz accessible to a wider audience. In his first chapter, Coker argues that Clausewitz was both in tune with his times and able to transcend them. This paradox creates the book's impetus and the rationale to examine Clausewitz's greatest preoccupations: how to win wars and what is the relationship between war and logic. To equip himself mentally for such questions, Clausewitz recognized and acknowledged the utility of unifying theories. Contrary to the opinions of many of his detractors Clausewitz was not a militarist, even though he was in love with war. He saw war as something that resided, however, unfortunately, in the human condition. The business of the strategist was to ameliorate the impact of this 'very imperfect political instrument, ${ }^{69}$ by seeking to minimize its duration and the effects on the society from which the strategist emerged. This necessitates a proper understanding of the relationship between political ends and military means in any given state and/or collection of states bound in alliance.

It is axiomatic that winning requires a proper understanding of war. This, in turn, requires a theory of war-fighting. This is the focus of Coker's chapter two. And Coker's re-born Clausewitz is openly critical of a great deal of contemporary military theory. Such theory tends to focus on information but is thin on substance. Determined to avoid wasteful distractions, in his West Point seminar Clausewitz repeats his maxim that war remains, fundamentally, 'an act of violence to compel an enemy to do our will'. This simple formulation belies the fact that there exists a variety of victories, and different modes of will and assorted clashes of combatant will. ${ }^{70}$ Clausewitz's trinity casts the nature of war as the interplay of three fundamental elements: reason, passion and chance. ${ }^{71}$ Coker does a particularly enlightening job in illuminating the ineradicable complexity of emotions that correlates with the changing culture of societies, and the increasing number of actors, ${ }^{72}$ which greatly complicate the conduct of modern war. The expanding complexity of the world today is a stimulus to good Clausewitzian analysis rather than the other way around. To attain victory, one must understand the relationships between these elements, the continuities and differences in war, and then see how they shape the conflict at hand. It all comes back to the need for a unifying theory of everything. In short, to know what kind of intelligence to collect, what type of strategy to design, you need a theory. In Rebooting Clausewitz, Coker, intriguingly, favours a combination of Darwin and Clausewitz as offering for what he sees as optimum theoretical model.

In chapter three of Rebooting Clausewitz (entitled 'What if Clausewitz had Read Darwin?'), Coker argues that Clausewitz's thinking was primed for a Darwinian approach. Coker disagrees with authors like Martin van Creveld (whose 1991 book On Future War was advertised as 'The most radical reinterpretation of armed conflict since Clausewitz' $)^{73}$ and their belief in the outdated nature of On War. ${ }^{74}$ Neither has Coker much time for certain authors, like the American strategist-economist Thomas Schelling, ${ }^{75}$ who assume that 'cool-headed' behaviour ordinarily underlies threats and responses. Coker's Clausewitz posits that 'war is a continuation of politics by other means but is not hostile to culture: politics is actually its sub-text .$^{76}$ His view of culture is Darwinian and, accordingly, emotions are both psychological and cultural. War is thus embedded in an evolutionary process. This evolutionary process, while influenced in part by biology, is ultimately cultural (and not to be confused with the notion of 'Social Darwinism' that was once so fashionable). ${ }^{77}$ This is Coker's way of marrying the diachronic in human history with the dynamic character of our societies. In a section where Coker revisits Clausewitz's phenomenology of war (his analysis of the origins, mechanisms, ontogeny and functions of war) is a real tour de force that surpasses the original. ${ }^{78}$ Less dynamic approaches than Coker's will, in future, come up short. In this sense, Coker's work is scientific. For some readers, this process will be more seductive than that adopted by, for instance, 
the eminent military historian Sir Michael Howard, whose deconstruction of strategic epochs focused rather more on careful historical analysis. ${ }^{79}$

Coker's Darwinist propositions address one of the biggest criticisms that the US Intelligence Community (IC) has faced recently: viz. that it does not 'do' theory. ${ }^{80}$ Indeed, on a generic level, the debates as to the utility of a unifying theory is one that has raged in Intelligence Studies for years now. ${ }^{81}$ Coker relishes such debates and rarely shies away from a fight. In highlighting the evolutionary complexity and unpredictability of war, Coker demonstrates why airbrushing reality is deeply counterproductive. 'Trend analysis is the only method we have of anticipating future trends within' Clausewitz's conceptual framework. ${ }^{82}$ The IC needs to engage with interpretations of alternative trends, and pinpoint the degrees of plausibility of its evaluations, so that policy makers do not overestimate the degree to which the evidence supports the conclusions. This will clash with what Robert Jervis terms '[the policymaker's] desire for greater certainty and the intelligence business model which now thrives on speed more than accuracy'. ${ }^{83}$ For US intelligence professionals, attempting to fit all the required information into, for example, the (US) President's Daily Brief (PDB), ${ }^{84}$ is certainly an Olympian task. But Coker makes a good case for the utility of evolutionary theory in dealing with such assignments. Indeed, such an analytical tool could well assist the US IC in achieving its central mission task - of 'speaking truth unto power' - more effectively.

The misguided notion that innovations like 'big data', the RMA and 'full-dimensional protection', have rendered Clausewitzian thought obsolete is thoroughly discredited by Coker. The misunderstandings arising out of the impact of these developments upon fundamentals such as the nature of war, and the character of conflict, are obviously a cause of some irritation for Coker. Coker is but the latest of a long line of scholars to lament the repeated misinterpretations of Clausewitz. As Basil Liddell Hart, for instance, noted:

As so often happens, Clausewitz's disciples carried his teaching to an extreme which their master had not intended...[his] theory of war was expounded in a way too abstract and involved for ordinary soldier-minds, essentially concrete, to follow the course of his argument - which often turned back from the direction in which it was apparently leading. Impressed yet befogged, they grasped at his vivid leading phrases, seeing only their surface meaning, and missing the deeper current of his thought. ${ }^{85}$

To rebut such wrongheadedness Coker invokes certain concepts - e.g., Clausewitz's concept of the 'fog of war' - to demonstrate the timelessness of On War. (And Coker's Clausewitz reminds us, that 'no state goes down without a fight for fear of losing its soul'). ${ }^{86}$ How to win efficiently is, Coker asserts, something the US military has largely forgotten how to do. Its military culture is, in terms of the grasp of basics in classical strategy, simply inadequate. Coker lambasts the 'a-strategic' nature of US military culture and demonstrates Clausewitz's point with a Darwinian breakdown of the social complexity of the post-2003 conflict in Iraq, and the development of the resistance forces there. This analysis culminates in a damning indictment of US policy which, however unwittingly, 'created [the] conditions in which the seeds of Islamic State [ISIS] were sown'. ${ }^{87}$

In war, it is axiomatic to declare that good intelligence is a prerequisite of victory (although when victory is attained with limited or no evidence of intelligence activity, its influence is often assumed). Contrary to popular misconceptions Clausewitz was intensely aware of the value of intelligence at all levels, but he was famously also highly sceptical of the accuracy of a large proportion of military intelligence. That this was so, was generally derived from phenomena that Clausewitz termed the 'fog of war' and 'friction'. It is in response to these two negatives that Clausewitz develops his concept of 'military genius'. ${ }^{88}$ This, naturally, is of great advantage in the realm of how leaders use intelligence. ${ }^{89}$ For Clausewitz, 'military genius' is not just a matter of intellect but, rather, an admixture of intellect with personality, courage, experience, personality and temperament. If sufficient of these qualities are present in sufficient quantity, then one might be able to nullify the effects of the 'fog of war' and 'friction'. ${ }^{90}$ Clausewitz's argues forcefully that 'friction' will always create significant difficulties for the implementation of any war plan, while the 
'fog of war' will always hinder commanders in their attempts to get a picture of what is happening. ${ }^{91}$

\begin{abstract}
Many intelligence reports in war are contradictory; even more are false, and most are uncertain. What can one reasonably ask of officer is that he should possess a standard if judgment, which he can gain only from knowledge of men and affairs and from common sense. He should be guided by the laws of probability. These are difficult enough to apply when plans are drafted in an office, far from the sphere of action; the task becomes infinitely harder in the thick of fighting itself, with reports streaming in. At such times one is lucky if their contradictions cancel each other out, and leave a kind of balance to be critically assessed. It is much worse for the novice if chance does not help him in that way, and on the contrary one report tallies with another, confirms it, magnifies it, lends it color, till he has to make a quick decision - which is soon recognized to be mistaken, just as the reports turn out to be lies, exaggerations, errors, and so on. In short, most intelligence is false, and the effect of fear is to multiply lies inaccuracies. ${ }^{92}$
\end{abstract}

Even so, such suspicious remarks were written in relation to intelligence at the tactical and operational levels. At the strategic and political levels, by contrast, Clausewitz repeatedly reiterated the absolute necessity of (high-level) political and strategic and political intelligence. Naturally, Clausewitz's writings were based on his own experiences as a soldier, and one should recall that his Prussian army was inferior to the contemporary French army in military intelligence, ${ }^{93}$ as in virtually every respect, due not least to the 'systemic' approach of Napoleonic warfare. ${ }^{94}$ Thus, while Clausewitz is sometimes accused of disregarding intelligence, this is simply not true (He did, however, note its limitations in his day - many of which have been overcome since, not least by advances in technology). ${ }^{95}$ Loch Johnson recently observed that Clausewitz's observation that most intelligence reports were 'contradictory', 'false' and 'uncertain' was entirely 'prescient'. Indeed, '[t]he same is true in times of peace': a 'reality about the limits of intelligence woven like a dark thread through [the study of intelligence]. ${ }^{96}$ General Flynn was, therefore, singing from the same hymn sheet as Clausewitz when he aimed for population-centric information. Such sources may offer 'few clues about where to find insurgents', but they will 'provide elements of ever great strategic importance - a map for leveraging popular support and marginalizing the insurgency itself'. ${ }^{97}$ Matt C. Zeller, a US Army veteran of the post-2001 Afghan War, pithily terms counterinsurgency (COIN) warfare as 'a thinking man's fight'. ${ }^{98}$ Such a moniker leads us directly to Clausewitz. Above all, Clausewitz instils in one a strong impulse to think about war.

In chapter five of Rebooting Clausewitz, which relates the narrative of the meeting of the Military History Circle in London, Coker's Clausewitz considers fighting contemporary wars by means of a discussion of the most productive way to read military history. In the light of Coker's previous arguments, the 'human space' in war is deemed preeminent here. Getting to grips with moral conundrums, such as the ones we inevitably face in war, 'involves, at least in part, locating [their] historical source... and to take seriously the deeply contingent nature of the tradition that we call "the ethics of war"'. Coker has little time for approaches that reduce the conduct of war to simple perceptions about power that 'raid' history merely for justificatory data. Context is everything, as it helps us attach value to the elements of the trinity of reason, passion, and chance. ${ }^{99}$ In and of itself, 'big data' collection cannot shed adequate light on emerging (and accelerating) patterns of social dynamism. This is the central problem with the Western way of war today. Pentagon planning for the 2003 invasion of Iraq, for example, typified the flawed thought process whereby such powerful institutions think they have re-invented and tamed war. ${ }^{100}$

A truth all too often lost on the Pentagon and other strategists in the US is that other nations (and cultures) still fight differently from the Western (or the American) way of war (The dreaded phenomenon of 'mirror-imaging', as ever, remains a potentially deadly pitfall). ${ }^{101}$ As war constantly mutates, vain attempts at disciplinary 'gate-keeping' of the definitions of the 'meaning of war' will only put one at a potentially lethal disadvantage. The idea of 'new wars' is based on such a fallacy, detracting from the complexity of the phenomenon of war itself. Once you start demarcating forms of 'knowledge', dismissing groups such as the Islamic State (ISIS) as a throwback to the Medieval era becomes all too easy (as the United States learned to its cost in Vietnam; and the Soviets did 
similarly in Afghanistan). In today's turbulent and increasingly fractured world, digesting military history teaches us not to underestimate one's enemies. As US Director of National Intelligence James Clapper stated in 2014:

What we didn't do was predict the will [of the Islamic State] to fight. That's always a problem. We didn't do it in Vietnam. We underestimated the Viet Cong and the North Vietnamese and overestimated the will of the South Vietnamese. In this case, we underestimated ISIL [the Islamic State] and overestimated the fighting capability of the Iraqi army. .. I didn't see the collapse of the Iraqi security force in the north coming. I didn't see that. It boils down to predicting the will to fight, which is an imponderable. ${ }^{102}$

Clausewitz knew only too well of such potential pitfalls in war - and his insights here typify the soundness of the philosophical tenets with which he sought to understand war. In his 'Testimonial', one passage would have resonated particularly with the Viet Cong or the (Kurdish) Peshmerga as Clausewitz identified '[f]ighting for the fatherland' as the soldier's greatest motivation. And, as an analysis of the nature of asymmetric war it is hard to dissent from Clausewitz's view that '[t]he history of our times demonstrates to us that the most forceful war can be waged with little money; but only with a great deal of courage and good will'. ${ }^{103}$

In the final chapter of Rebooting Clausewitz, Coker briefly compares the Prussian thinker to Thucydides and Sun Tzu. This short chapter provides valuable food for thought with Thucydides' scoring some points over Clausewitz. What unites the Athenian and the Prussian is their shared emphasis on the centrality of emotions in war. And, in this, Coker's Rebooting Clausewitz comes full circle. Admittedly, Coker's intellectual achievement with Rebooting Clausewitz comes at the price of some distortion. ${ }^{104}$ A case in point being the adoption of an ambiguous view of Clausewitz on the issue of victory. Traditional takes on Clausewitz's view of victory have argued that he more focused on military victory than anything else. Indeed, Coker himself has written that 'Clausewitz tended to ascribe success and failure in war to decisive battlefield encounters, and to attribute victory or defeat to the genius of a particular general'. ${ }^{105}$ But, in truth, Clausewitz's views on this subject continued to evolve throughout his life. Coker has a thought-provoking but brief discussion on Clausewitz's Eurocentrism, and this could have been expanded. It is interesting to read that Clausewitz was not Eurocentric in the sense that 'he did not postulate an unchanging Western way of war'. ${ }^{106}$ This raises the question of Eurocentrism. In this ever-evolving (Western) 'Way of War', the question is whether the non-West can have any real impact and/or agency. Such a question is compatible with the Clausewitzian framework as set out here, and raises intriguing matters for future research. ${ }^{107}$

The four pieces comprising Clausewitz and Small War ('Lectures on Small War' (1810-1811); the Bekenntnisdenkschrift (1812); on the Landwehr (1819) and on Volksbewaffnung (1832)) mirror the evolution of Clausewitz's thinking on the national security needs of Prussia in the last two decades of his life. The Napoleonic era had seen Europe shift from the limited wars of the era of Frederick the Great (r. 1740-86) to national wars. ${ }^{108}$ It was this change that prompted Clausewitz to observe of the French revolutionary armies:

\footnotetext{
Suddenly war again became the business of the people - a people of thirty millions, all of whom considered themselves to be citizens...The people became a participant in war; instead of governments and armies as heretofore, the full weight of the nation was thrown into the balance. The resources and efforts now available for use surpassed all conventional limits; nothing now impeded the vigour with which war could be waged, and consequently the opponents of France faced the utmost peril. ${ }^{109}$
}

Following the defeat of Prussia by Napoleon in 1806 Clausewitz increasingly focused on the evolving role of the people in war - a subject that constituted an ever-increasing factor in his evolving Trinity. In a 2017 review of Clausewitz on Small War, Timothy D. Hoyt opined that the book itself offered 'a metaphor for Clausewitz's remarkable trinity'.

In these translations we see Clausewitz the officer, Clausewitz the patriot, and Clausewitz the scholar/analyst a personal manifestation of the forces of chance, accident and probability (nested largely in the military), 
primordial violence, hatred and enmity (found largely in the people), and rationality (found in the political leadership). The trinity, in turn, provides the foundations for his discussions of how and why the character of war can and has (in his time) changed. ${ }^{110}$

In the wake of Napoleon's innovations, the theory of war espoused in Clausewitz's On War was undoubtedly a response to contemporary developments in mathematics and philosophy, and the tools for solving military problems - maps, war games, simulations, and the like - became models for how to manage chance. ${ }^{111}$ And, ever since 1932, contemporary debates over the continued relevance of Clausewitz have many antecedents. And such debates will undoubtedly continue. ${ }^{112}$ One of the most eminent of Clausewitz scholars, Peter Paret, has argued that it is not the case 'that one must be a historian of his period or a biographer of his life to be critically receptive of his work in its final state - the reaction Clausewitz hoped for from his readers'. ${ }^{113}$ In his introduction to Clausewitz and Small War, James W. Davis observes that:

Ultimately, [for Clausewitz] war is an act of violence (Gewalt) intended to compel the enemy to submit to a foreign will. ${ }^{114}$ A close reading of Clausewitz's writings on Small War leads to the conclusion that he did not have a fixed conception of the political organizations that might adopt means or of the form the ensuing clash of wills would take. Rather, it is that which unifies warfare despite the diversity of its empirical forms that interested him. ${ }^{115}$

In today's world, Clausewitz's belief in the utility of force (or at least an acceptance that it is the way things are), and of the necessity of keeping political and military goals in close alignment continues to shape international politics. ${ }^{116}$ And make no mistake about it - even for the United States the idea of exactly how to use its overwhelming military power is problematic ${ }^{117}$ (A 2014 book by Coker even posed the question as to whether war could be abolished). ${ }^{118}$ In Rebooting Clasuewitz, Coker makes his case for the enduring legacy of Clausewitz with verve and passion. Rebooting Clausewitz is packed with insightful nuggets, for both the advanced reader and the uninitiated individual (although it is obviously written with an eye to undergraduate students of war, strategy and military history). It will serve those seeking to understand Clausewitz particularly well. This is important not least because it is with good reason that Clausewitz remains required reading in military academies and universities worldwide. ${ }^{119}$

Historically, part of the problems with the interpretation of Clausewitz lies in the expectations of his readers prior to studying him. And Clausewitz, more than most philosopher intellectuals, can be read in a number of different ways. It is, for instance, not uncommon for On War to be labelled as a primarily normative text. In doing this, one will most likely come to deem Clausewitz's theories as the basis of what one should do in any war. On War can also be read, of course, as a descriptive document. In this scenario On War is supposed to make the reader understand that, if Clausewitz's most famous dictum (about war being 'a continuation of political intercourse, carried on with other means') ${ }^{120}$ is treated as irrefutable fact, it will soon lead 'to the conclusion that On War is first and foremost an effort to uncover objective knowledge about the phenomenon of war rather than as a primer on military, let alone political, strategy'. ${ }^{121}$ For Timothy Hoyt the case Clausewitz's continuing relevance is clear.

[Clausewitz's] discernment of the power of a people in arms, mobilized by patriotism or ideology and willing to make great sacrifices to achieve victory, should be fundamental for those considering wars that will require occupation. Clausewitz's critics, as always, will argue that because he does not provide simple answers to specific complex contemporary problems, he has nothing to offer. The fact that the United States has, in this century, pursued two wars of unlimited aims (with the explicit objective of overthrowing an existing regime), and then faced the quandary of counterinsurgency and state building, should suggest that Clausewitz is as relevant to strategic calculations today as ever. ${ }^{122}$

In Rebooting Clausewitz Coker made the central mission of this book the demonstration that war evolves 'in sync' with humanity, not least because war is the ultimate human activity ${ }^{123}$ (Or, as Thucydides termed it, the 'human thing'). ${ }^{124}$ Any theory of war, as Coker maintains throughout his volume, 'must never lose sight of the human dimension of life'. ${ }^{125}$ Indicative of his concurrence on this point of necessity, Clausewitz wrote in his 'Testimonial': 
It is commonly held that the enemy can deprive us of the necessary courage through cruel treatment of captured insurgents, through the death penalty, etc. But what an unnecessary concern! As if we could not be as cruel as the enemy, as if the enemy would not consist of flesh and blood! The enemy will indeed try to use such means, and the war will rapidly acquire a barbarous quality. But to whose disadvantage? Obviously to the disadvantage of those who can put fewer lives on the line, who fight with standing armies! So let us take our chances and answer cruelty with cruelty, respond to atrocities with atrocity. It would be easy for us to exceed the enemy and to force him back into the bounds of moderation and humanity. ${ }^{126}$

In a previous book Coker asked, 'how can we even aspire to peace if we cannot reliably know what other people hold most dear?'127 China's military and security agenda, naturally, attracts a great deal of attention in the West (as US DNI Clapper observed in 2014: 'I'm looking at what I find [to be] impressive and disturbing programs, across the board, which the Chinese have embarked on to modernize their military in all branches and all realms, including cyber and space. It's very impressive what they're doing.') ${ }^{128}$ In China itself persistent interest in the 'masters' of Western strategic thought means that Rebooting Clausewitz was published in Chinese in 2018. ${ }^{129}$ Small wonder: the Chinese, just like everyone else, want to read the latest primer on Clausewitz for the twenty-first century.

\section{Notes}

1. Clausewitz, On War, 75. Italics in the original.

2. At the time McChrystal was the Commander, International Security Assistance Force (ISAF) and Commander, U. S. Forces Afghanistan (USFOR-A). Increasing difficulties for the US forces in Afghanistan led to his dismissal by President Barack Obama in 2010. Wilson and Shear, "Obama relieves McChrystal of his duties."

3. Michael Thomas Flynn, a retired Lieutenant General, served in the US Army from 1981 until 2014. During his time in the military, Flynn played an important role in formulating US counterterrorism strategies and combating insurgent networks in Afghanistan and Iraq from 2001 onwards. In 2012, Flynn was appointed by President Barack Obama as director of the Defense Intelligence Agency (DIA). He served in this role until he retired in the summer of 2014. After leaving the US Army, he established the Flynn Intel Group - providing intelligence and analysis for governments and businesses alike. He has recently secured unwanted notoriety through his association with the Trump administration: having served as President Trump's first National Security Advisor. In February 2017, Flynn had to resign after it emerged that he had lied to Vice-President Pence about the nature, and the content, of his communications with the Russian ambassador to the U.S. (Sergey Kislyak). Flynn's involvement in the so-called 'Russiagate' scandal means that his tenure as National Security Advisor for just 24 days (20 January to 13 February 2017) set a record for being the shortest in the history of the office. There is speculation that Flynn would testify before the FBI and Congress about possible links between the Trump presidential campaign of 2016 and Russia in exchange for immunity from prosecution. See, for example, Sabrina Siddiqui (Washington DC), 'Mike Flynn indicates he would testify in TrumpRussia inquiry in exchange for immunity.' The Guardian (London), 31 March 2017. https://www.theguardian. com/us-news/2017/mar/30/michael-flynn-trump-russia-investigation-testify-immunity (accessed 8 August 2017). In August 2017 it was reported that Flynn had revealed his brief role in an advisory position for a firm related to a controversial data analysis company that aided the Trump campaign in 2016. Associated Press (Washington DC), 'Michael Flynn to disclose advisory role linked to Cambridge Analytica', The Guardian (London), 4 August 2017. https://www.theguardian.com/us-news/2017/aug/04/michael-flynn-cambridge-analytica-disclosure (accessed 3 September 2017). In December 2017, Flynn pleaded guilty to lying to the FBI about conversations with the Russian ambassador in December 2016. He thus became the first senior White House official to cooperate with the special counsel's inquiry into the 2016 presidential election. Michael D. Shear and Adam Goldman, 'Michael Flynn Pleads Guilty to Lying to the F.B.I. and Will Cooperate With Russia Inquiry', New York Times, 1 December 2017. On January 292018 one official involved with the investigation, FBI Deputy Director Andrew McCabe, charged with partisanship by Trump, was forced to step down ahead of his official retirement date in March 2018. BBC News, 'Andrew McCabe, FBI deputy director, quits after Trump criticism', http://www.bbc.co.uk/news/world-us-canada-42865202 (accessed 29 January 2018). After his plea bargain, the sentencing of Flynn has been deferred several times, and is now set for 18 December 2018. Chad Day (Associated Press), "Ex-Trump national security adviser Michael Flynn sentencing set for Dec. 18," USA Today, 20 September 2018.

4. The report was released in March 2009 by the Wikileaks site, whose commentary noted that 'The 318 page document could be described as part of the "Pentagon Papers" for Iraq and Afghanistan.' 'Major RAND study with 300 interviews: Intelligence Operations and Metrics in Iraq and Afghanistan, Nov 2008', released 
2 March 2009. https://wikileaks.org/wiki/Major_RAND_study_with_300_interviews:_Intelligence_Operations_ and_Metrics_in_Iraq_and_Afghanistan,_Nov_2008 (accessed January 26, 2018). 'The Pentagon Papers' was the critical top secret report on Vietnam that was leaked to the press in 1971.

5. Beaumont, "Intelligence failures crippling fight against insurgents in Afghanistan, says report".

6. 'Major RAND study with 300 interviews', https://wikileaks.org/wiki/Major_RAND_study_with_300_interviews: _Intelligence_Operations_and_Metrics_in_Iraq_and_Afghanistan,_Nov_2008 (accessed 26 January 2018). The embarrassment of the CIA on occasion knows no bounds. In 2018 a 15-year-old British boy was found guilty of having hacked computer systems to gain access to plans for intelligence operations in Afghanistan and Iran by pretending to be the head of the CIA, John Brennan. Hayley Dixon, 'British 15-year-old gained access to intelligence operations in Afghanistan and Iran by pretending to be head of CIA, court hears', Daily Telegraph, 19 January 2018.

7. Kitfield, "America's Angriest General".

8. Jervis, Why Intelligence Fails.

9. Jervis, "H-Diplo Roundtable Review," 28.

10. Clausewitz, On War, 87.

11. Bassford, Clausewitz in English, 198.

12. Luttwak quoted in Achenbach, "War and the Cult of Clausewitz".

13. Paret, Makers of Modern Strategy, 213.

14. Bellinger, Marie von Clausewitz. Bellinger uses newly discovered correspondence to assess Marie von Clausewitz's influence over her husband's book, On War - published posthumously by her in 1832 - and analyses the social and cultural climate in which the couple lived.

15. Bellinger, " 5 Secrets of Carl von Clausewitz".

16. On this, see Jay Luvaas, "Clausewitz, Fuller", 197-212; and Sir Basil Liddell Hart (1895-1970) was a British soldier, military historian and military theorist.

17. Grayling, War, 108.

18. See, for example: Keegan, A History of Warfare. Sir John Keegan (1934-2012) was a British military historian, lecturer, author and journalist.

19. Trans: 'Carthage must be destroyed'. A phrase used in the Roman Republic prior to the Third Punic War against Carthage and especially associated with Cato the Elder (who supposedly used it at the conclusion to end all his speeches).

20. Bassford, "John Keegan and the Grand Tradition of Trashing Clausewitz," 319.

21. Sun Tzu (c.544BC-c.496BC) was a Chinese general, military strategist, and philosopher.

22. In the eighteenth century, Voltaire asserted that 'Machiavelli taught Europe the art of war; it had long been practiced, without being known'. 'Introduction' to Niccolò Machiavelli, The Art of War, revised edition of the Ellis Farneworth translation, with an introduction by Neal Wood (New York: Da Capo, 2001 [1521]) xxxii.

23. Antoine-Henri Jomini (1779-1869) was a Swiss-born Napoleonic general and strategist who later served with the Russian army. On Jomini, see Shy, "Jomini" in Paret, ed., Makers of Modern Strategy, 143-185.

24. Handel, Masters of War, xxiv.

25. Handel, Masters of War, xviii-xix. Quote at xviii.

26. Kant and Humphrey, Perpetual Peace and Other Essays.

27. Kant quoted (his italics) in Papish, Kant on evil, self-deception, 209.

28. Moran, "Introduction", Kant on Freedom, 1.

29. Clausewitz, On War, 80.

30. Clausewitz, On War, 111; Charles XII took Sweden to the peak of its power through his brilliant victories, although the Great Northern War (1700-21) eventually ended in Sweden's defeat and the end of its empire. The main beneficiary of this was the Russia of Peter I. On this, see Ragnhild, "Charles XII and the Great Northern War", 648-80.

31. Voltaire (François-Marie Arouet), The history of Charles XII, 51.

32. Howard, Clausewitz, 49; 'Der politische Zweck des Krieges kann doppelter Art sein. Entweder den Gegner ganz zu vernichten, seine Staatenexistenz aufzuheben, oder ihm beim Frieden Bedingungen vorzuschreiben.' (Trans: 'The political purpose of war can be twofold. Either to destroy the opponent altogether, to abolish his state's existence, or to dictate peace conditions to him.') von Clausewitz, Strategie aus dem Jahr 1804, 20; and Herberg-Rothe, Das Rätsel Clausewitz, 130.

33. Clausewitz, The Campaign of 1812 in Russia, 253.

34. Most of these have been available in German for many years. Most notably in Hahlweg (ed.), Carl von Clausewitz, 2 volumes.

35. Christopher Daase is Professor of International Organization, Goethe University of Frankfurt; James W. Davis is Professor of International Relations, University of St. Gallen.

36. On this, see Hahlweg, "Clausewitz and Guerrilla Warfare," 127-133. Daase and Schindler, "Clausewitz, Guerillakrieg und Terrorismus", 701-31.

37. Davis, "Introduction" to Clausewitz on Small War, 1-18. 
38. 'Lectures on Small War, held at the War College in 1810 and 1811' in Daase and Davis (eds), Clausewitz on Small War, 19-168. The Prussian War Academy (Preußische Kriegsakademie) was founded by Gerhard von Scharnhorst in 1810 as part of the response to Prussia's crushing defeats at Jena and Auerstadt by Napoleon in 1806. Craig, The Politics, 38-53. In terms of managing the business of waging war, the Prussian General Staff (Großer Generalstab) was unofficially founded in 1806 and established in law in 1814. Both the Preußische Kriegsakademie and the Großer Generalstab became the models for militaries worldwide. On this, see Görlitz, History of the German General Staff.

39. Clausewitz, "Testimonial (Bekenntnisdenkschrift)," in Daase and Davis (eds), Clausewitz on Small War, 169-216.

40. Clausewitz, "On the political advantages and disadvantages," in Daase and Davis (eds), Clausewitz on Small War, 217-220.

41. Clausewitz, "The arming of the people (Volksbewaffnung)," in Daase and Davis (eds), Clausewitz on Small War, 221-226. This is a new translation of Clausewitz's chapter in On War entitled "The People in Arms" (chapter 26 of book six of On War, 479-484).

42. After the defeat of 1806 Prussia lost territory and had its army limited in size through treaty with France. Clausewitz wrote on this in 1824-5, although it was not published until 1888. See Carl von Clausewitz, Nachrichten über Preussen in seiner grossen Katastrophe; and Carl von Clausewitz, "Nachrichten über Preussen in seiner grossen Katastrophe," 301-493.

43. Coker, Rebooting Clausewitz, 85-91.

44. Coker, Rebooting Clausewitz, 117.

45. Coker, Rebooting Clausewitz, 26.

46. In the twentieth century Hans J. Morgenthau (1904-1980) developed realism into a comprehensive international theory. Morgenthau identified six principles of political realism. His first principle identified realism as being located in objective laws that have their roots in human nature. Morgenthau, Politics among Nations, 4.

47. Coker, Rebooting Clausewitz, 113.

48. Coker, Rebooting Clausewitz, xiii.

49. Coker, Rebooting Clausewitz, 70.

50. Coker, Rebooting Clausewitz, 113.

51. On RMAs see Gray, Strategy for Chaos.

52. Waldman, War, Clausewitz and the Trinity.

53. Coker, Rebooting Clausewitz, 10.

54. Handel, Masters of War: Classical Strategic Thought, xxiv.

55. For Mao's thinking on war, see Mao, Six Essays on Military Affairs.

56. Clausewitz, On War, 593.

57. Kaldor, New \& Old Wars, 1-2.

58. Kaldor, "Inconclusive Wars: Is Clausewitz Still Relevant in these Global Times?," 271.

59. Davis, "Introduction to Clausewitz on Small War", 10.

60. Creveld, On Future War, 40.

61. Kaldor, New and Old Wars, 15.

62. Clausewitz, On War, 89.

63. Levy, "Clausewitz and People's War,"453.

64. Kaldor, "Inconclusive Wars," 272.

65. On this, see Puyvelde, Coulthart and Hossain, "Beyond the buzzword," 1397-1416.

66. Coker, Rebooting Clausewitz, 29-30.

67. McCabe, "Hegel and the Idea," 369-388.

68. Coker, Can War Be Eliminated?; and Coker, Future War.

69. Coker, Rebooting Clausewitz, 10.

70. Coker, Rebooting Clausewitz, 58, 29, 34. Quote at 29.

71. Despite its notoriety as a concept, Clausewitz dealt with the notion of the 'Trinity' on just one page of Vom Kriege. See Clausewitz, On War, 89. For a recent work on this, see Waldman's War, Clausewitz and the Trinity.

72. Coker, Rebooting Clausewitz, 47.

73. Van Creveld declared the work of Clausewitz, and all 'classical strategy', to be the 'product of specific periods and circumstances.' Van Creveld, On Future War, 206. That said, van Creveld still rated Clausewitz's On War as 'The second best book on war ever written.' On Future War, 231.

74. Coker, Rebooting Clausewitz, xv.

75. Thomas Schelling (1921-2016) was an American economist and scholar of foreign policy, national security, nuclear strategy, and arms control. He was a professor at the University of Maryland, College Park. In 2005, he was awarded the 2005 Nobel Memorial Prize in Economic Sciences (shared with Robert Aumann). His books include Schelling, The Strategy of Conflict; Schelling and Halperin, Strategy and Arms Control; and Schelling, Arms and Influence.

76. Coker, Rebooting Clausewitz, 64. 
77. The term Social Darwinism refers to various philosophies and theories that emerged in the second half of the nineteenth century when its proponents sought to apply the evolutionary concept of natural selection to human society. It reached its nadir in Nazi ideology between 1933 and 1945. On Social Darwinism, see Dickens, Social Darwinism.

78. Coker, Rebooting Clausewitz, 69-83.

79. Howard, The Lessons of History, 198-200.

80. Jervis, "The Politics and Psychology," 7-8.

81. On this, see Andrew, "Intelligence, International Relations," 170-184; and Hillebrand and Hughes, "The Quest for a Theory of Intelligence," 1-24.

82. Coker, Rebooting Clausewitz, 57.

83. Jervis, Why Intelligence Fails, 181.

84. The CIA webpage describes the President's Daily Brief (PDB) as the Directorate of Analysis' 'flagship' product. '[T] he PDB offer analysis that helps policy and security officials work through the core issues in the broader US policy agenda ... [It] compiles the Intelligence Community's highest level intelligence analysis targeted at the key national security issues and concerns of the President. The PDB is given only to the President, the Vice President, and a very select group of Cabinet-level officials designated by the President.' Central Intelligence Agency (CIA), 'Offices of the CIA: Products', https://www.cia.gov/offices-of-cia/intelligence-analysis/products. html (accessed 17 July 2017). On the PDB, see Wolfberg, "The President's Daily Brief," 225-58. For essential background, see Andrew, "American Presidents and their Intelligence Communities," 95-112; and Andrew, For the President's Eyes Only.

85. Liddell Hart, Strategy.

86. Coker, Rebooting Clausewitz, 99.

87. Coker, Rebooting Clausewitz, 103-4.

88. Clausewitz, On War, 100-12.

89. On this, see Handel, "Leaders and intelligence,"3-39.

90. Shepherd III, The Fog of War, 9-10.

91. On Clausewitz, military command and intelligence, see Ferris and Handel, "Clausewitz, Intelligence, Uncertainty and the Art," 1-58.

92. Clausewitz, On War, 117.

93. For an insight into Napoleon's use of intelligence in war, see LuvaasNapoleon's use of intelligence," 40-54. The Duke of Wellington made excellent use of intelligence in Spain, not least through the breaking of the enemy's codes by Major George Scovell. On this, see Urban, The Man who broke Napoleon's Codes.

94. As Simon Schama once noted: 'From the very beginning - from the summer of 1789 - violence was the motor of revolution.' Schama, Citizens, 690.

95. Hughes, "Strategists and Intelligence," 52-4; "Introduction: What is Intelligence?," 1; and Kahn, "Clausewitz and intelligence," 117-8.

96. Johnson, National Security Intelligence, 6-7.

97. Ackerman, "Michael Flynn".

98. Zeller, Watches Without Time, 1.

99. Coker, Rebooting Clausewitz, 141, 125. Quote at 141.

100. On this, see Prados and Ames (ed.), "THE IRAQ WAR - PART II".

101. The phenomenon of so-called 'mirror-imaging' in intelligence analysis (ordinarily by intelligence analysts, naturally) leads to dangerous assumptions. This arises out of a failure to acknowledge that people in different cultures approach the world in different ways, and think differently. The frequently-made assumption - that they do as we do. The accomplished intelligence analyst Raymond Garthoff referred to mirror imaging as a common 'fallacy', inherent in all analysis of intelligence. For Garthoff, this failing is derived from a propensity to 'project (usually implicitly and indeed unconsciously) onto the subject of the estimate one's views, perceptions, values and behavior'. Garthoff, "On Estimating and Imputing Intentions," 25. When summing up the assessment of the US Intelligence Community's lamentable failure to predict India's 1998 nuclear weapons tests (the so-called 'Pokhran II' programme), Admiral David Jeremiah (US Navy) strongly criticised the prevalence of a culture characterised by a 'everybody-thinks-like-us mind-set'. Jim Wolf, 'CIA Inquest Finds US Missed Indian "Mindset"', UPI wire service, 3 June 1998.

102. David Griffiths, 'James Clapper: We underestimated the Islamic State's "will to fight"', Washington Post, 18 September 2014. See also David Ignatius, 'From the Viet Cong to the Islamic State, the perils of underestimating the enemy's "will"', Washington Post, 22 September 2014.

103. "Testimonial (Bekenntnisdenkschrift)," 169-216.

104. Coker, Rebooting Clausewitz, 92.

105. Coker, Barbarous Philosophers, 174.

106. Coker, Rebooting Clausewitz, 85. 
107. The social and political conditions underpinning the varying willingness of weak city-states to take pain, and, hence, the variability of their agency beyond their mere material weakness in instances of surrender is explored in Koutsoukis, Challenging Victor Bias and Status Quo Bias in Realist Accounts of Surrender.

108. On this, see Bell, The First Total War.

109. Clausewitz, On War, 592.

110. Hoyt, "Clausewitz and Small Wars," 441.

111. On this, see Engberg-Pedersen, Empire of Chance.

112. One recent example being Souchon, Carl von Clausewitz und Strategie im 21. Jahrhundert.

113. Paret, Clausewitz in his Time, 8.

114. Clausewitz, On War, 75.

115. Davis, "Introduction to Clausewitz on Small War," 18.

116. Gat, The Origins of Military Thought, 215.

117. On this, see Koutsoukis, "Building an empire or not? Athenian imperialism," 12-30.

118. On this, see Coker, Can War Be Eliminated?, passim.

119. Hughes, "War as Political Violence," 358.

120. Clausewitz, On War, 87. Davis, "Introduction" to Daase and Davis (eds), Clausewitz on Small War, 5.

121. Davis, "Introduction to Clausewitz on Small War," 5.

122. Hoyt, "Clausewitz and Small Wars," 441.

123. Coker, Rebooting Clausewitz, 131.

124. Cartwright, A Historical Commentary on Thucydides, 5. For more on this concept, see Cogan, The Human Thing.

125. Coker, Rebooting Clausewitz, 58.

126. Clausewitz, "Testimonial (Bekenntnisdenkschrift)" in Daase and Davis (eds), Clausewitz on Small War, 205.

127. Coker, Future War, 210.

128. Griffiths, "James Clapper".

129. On Clausewitz and China, see Tiejun, "The Western Master and Bible of War," 42-59; and Meilinger, "China and Clausewitz," 325-326.

\section{Disclosure statement}

No potential conflict of interest was reported by the authors.

\section{Notes on contributors}

R. Gerald Hughes is Reader in Military History and Director of the Centre for Intelligence and International Security Studies at Aberystwyth University. He is the author of The Postwar Legacy of Appeasement: British Foreign Policy Since 1945 (2014) and Britain, Germany and the Cold War: The Search for a European Détente, 1949-1967 (2007). A review editor of Intelligence and National Security, Hughes is the author of a large number of book chapters and articles (most recently "'Fear has large eyes": The History of Intelligence in the Soviet Union' in the Journal of Slavic Military Studies; and 'Between Man and Nature: The Enduring Wisdom of Sir Halford J. Mackinder' in the Journal of Strategic Studies). $\mathrm{He}$ is the editor, or co-editor, of a number of scholarly volumes including: The Cuban Missile Crisis: A Critical Reappraisal (2016); Intelligence and International Security: New Perspectives and Agendas (2011); Intelligence, Crises and Security: Prospects and Retrospects (2008) and Exploring Intelligence Archives: Enquiries into the Secret State (2008). R. Gerald Hughes is a Fellow of the Royal Historical Society.

Alexandros Koutsoukis teaches at Aberystwyth University having recently successfully defended his PhD dissertation on the concept of 'surrender' in the Peloponnesian War there. He is editorial assistant for the Kantian Review and the author of 'Building an Empire or Not? Athenian Imperialism and the United States in the 21st Century' in Foster, Johnson and Edward (eds), The Crisis of the Twenty-First Century: Empire in the Age of Austerity (2014). In 2008, he

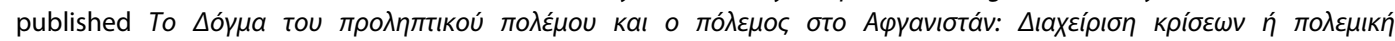

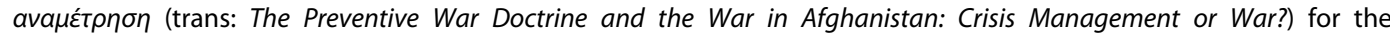
Hellenic Foundation for European and Foreign Policy (ELIAMEP).

\section{Bibliography}

Achenbach, J. "War and the Cult of Clausewitz." Washington Post, December 6, 1990.

Ackerman, S. "Michael Flynn: From Subtle Intelligence Chief to Muslim-Baiting Ideologue." The Guardian (London), November 18, 2016. Accessed July 14, 2017. https://www.theguardian.com/usnews/2016/nov/18/michael-flynnnational-security-adviser-profile 
Andrew, C. "American Presidents and Their Intelligence Communities." Intelligence and National Security 10/4 (1995): 95-112. doi:10.1080/02684529508432327.

Andrew, C. For the President's Eyes Only: Secret Intelligence and the American Presidency from Washington to Bush. New York: HarperCollins, 1995.

Andrew, C. "Intelligence, International Relations and 'Under-Theorisation'." Intelligence and National Security 19/2 (2004): 170-184. doi:10.1080/0268452042000302949.

Andrew, C., Aldrich, R. J. and Wark, W. K. "Introduction: What is Intelligence?." In Secret Intelligence: A Reader, edited by Christopher Andrew, Richard J. Aldrich and Wesley K. Wark, 1-2. Abingdon, Oxon: Routledge, 2009

Associated Press (Washington DC). "Michael Flynn to disclose advisory role linked to Cambridge Analytica." The Guardian, August 4, 2017. London. Accessed September 3, 2017. https://www.theguardian.com/us-news/2017/aug/ 04/michael-flynn-cambridge-analytica-disclosure

Bassford, C. "John Keegan and the Grand Tradition of Trashing Clausewitz." War in History 1/3 (1994): 319-336. doi:10.1177/096834459400100305.

Bassford, C. Clausewitz in English: The Reception of Clausewitz in Britain and America, 1815-1945. New York, NY: Oxford University Press, 1994.

Beaumont, P. "Intelligence failures crippling fight against insurgents in Afghanistan, says report", The Guardian (London), 6 March 2009.

Bell, D. A. The First Total War: Napoleon's Europe and the Birth of Modern Warfare. London: Bloomsbury, 2007.

Bellinger, V. E. Marie Von Clausewitz: The Woman behind the Making of on War. New York, NY: Oxford University Press USA, 2016.

Bellinger, V. E. "5 Secrets of Carl von Clausewitz," The National Interest, January 26, 2016. Accessed September 25, 2018. https://nationalinterest.org/blog/the-buzz/5-secrets-carl-von-clausewitz-15024

Cartwright, D. A Historical Commentary on Thucydides: A Companion to Rex Warner's Penguin Translation. Ann Arbor, MI: University of Michigan Press, 1991.

Central Intelligence Agency (CIA). "Offices of the CIA: Products." 2017. Accessed July 17, 2017. https://www.cia.gov/ offices-of-cia/intelligence-analysis/products.html

Clausewitz, C. von. Nachrichten über Preussen in seiner grossen Katastrophe. Berlin: Mittler, 1888.

Clausewitz, C. von. "Nachrichten über Preussen in seiner grossen Katastrophe." In Verstreute kleine Schriften, ed. W. Hahlweg, 301-493. Vol. 1979. Osnabrück: Biblio Verlag, 1888.

Clausewitz, C. von. On War. Edited by M. Howard and P. Paret. Introductory essays by Peter Paret, Michael Howard and Bernard Brodie. Commentary by Bernard Brodie, Princeton, NJ: Princeton University Press, 1984 [1832].

Clausewitz, C. von. Foreword by Sir Michael Howard. The Campaign of 1812 in Russia. New York: Da Capo Press, 1995.

Clausewitz, C. von., and E. Kessel, Edited by. Strategie aus dem Jahr 1804, mit Zusätzen von 1808 und 1809. Hamburg: Hanseatische Verlagsanstalt, 1937.

Clausewitz, C. von. "Lectures on Small War, held at the War College in 1810 and 1811." In Clausewitz on Small War, edited by Daase and Davis, $9-168$.

Clausewitz, C. von. "Testimonial (Bekenntnisdenkschrift)." In Clausewitz on Small War edited by Daase and Davis, 169-216.

Clausewitz, C. von. "On the political advantages and disadvantages of the Prussian institution of the Landwehr." In Clausewitz on Small War, edited by Daase and Davis, 217-220.

Clausewitz, C. von. "The arming of the people (Volksbewaffnung)." In Clausewitz on Small War, edited by Daase and Davis, 221-226.

Cogan, M. The Human Thing: The Speeches and Principles of Thucydides' History. Chicago, IL: University of Chicago Press, 1981.

Coker, C. Rebooting Clausewitz: On War in the 21st Century. London: Hurst \& Company, 2017.

Coker, C. Barbarous Philosophers: Reflections on the Nature of War from Heraclitus to Heisenberg. London: Hurst \& Company, 2010.

Coker, C. Can War Be Eliminated? Cambridge: Polity, 2014.

Coker, C. Future War. Cambridge, MA: Polity, 2015.

Craig, G. A. The Politics of the Prussian Army 1640-1945. Oxford: Oxford University Press, 1955.

Daase, C., and S. Schindler. "Clausewitz, Guerillakrieg und Terrorismus: Zur Aktualität einer missverstandenen Kriegstheorie." Politische Vierteljahresschrift 50/4 (2009): 701-731. doi:10.1007/s11615-009-0153-2.

Davis, J. W. "Introduction to Clausewitz on Small War." In Clausewitz on Small War, edited by C. Daase and J. W. Davis, 1-18. Oxford: Oxford University Press, 2015.

Day, C. (Associated Press), "Ex-Trump national security adviser Michael Flynn sentencing set for Dec. 18", USA Today, 20 September 2018.

Dickens, P. Social Darwinism: Linking Evolutionary Thought to Social Theory. Philadelphia, PA: Open University Press, 2000.

Engberg-Pedersen, A. Empire of Chance: The Napoleonic Wars and the Disorder of Things. Cambridge, MA: Harvard University Press, 2015.

Ferris, J., and M. I. Handel. "Clausewitz, Intelligence, Uncertainty and the Art of Command in Military Operations." Intelligence and National Security 10/1 (1995): 1-58. doi:10.1080/02684529508432286.

Garthoff, R. L. “On Estimating and Imputing Intentions." International Security 2/3 (1978): 22-32. doi:10.2307/2538512. 
Gat, A. The Origins of Military Thought: From the Enlightenment to Clausewitz. New York: Oxford University Press, 1989. Görlitz, W. History of the German General Staff, 1657-1945. Boulder, CO: Westview Press, 1985.

Gray, C. S. Strategy for Chaos: Revolutions in Military Affairs and the Evidence of History. London: Frank Cass, 2002. Grayling, A.C. War: An Enquiry. Yale, CT: Yale University Press, 2017.

Griffiths, D. 'James Clapper: We Underestimated the Islamic State's "Will to Fight"', Washington Post, September 18, 2014. Hahlweg, W., ed. Carl von Clausewitz: Schriften, Aufsätze, Studien, Briefe. Vol. 2. Göttingen: Vandenhoeck \& Ruprecht, 1966. Hahlweg, W. "Clausewitz and Guerrilla Warfare." In Clausewitz and Modern Strategy, edited by M. I. Handel, 127-133. London: Frank Cass, 1986.

Handel, M. I. Masters of War: Classical Strategic Thought. 3rd rev ed. New York: Frank Cass, 2001.

Handel, M. I. "Leaders and Intelligence." Intelligence and National Security 3/3 (2008): 3-39.

Hart, L., and H. Basil. Strategy. 2nd rev ed. London: Faber, 1967.

Hatton, R. M. "Charles XII and the Great Northern War." In New Cambridge Modern History, Volume VI, the Rise of Great Britain and Russia 1688-1725, edited by J. S. Bromley, 648-680. Cambridge: Cambridge University Press, 1970.

Herberg-Rothe, A. Das Rätsel Clausewitz: Politische Theorie des Krieges im Widerstreit. Munich: Wilhelm Fink Verlag, 2001. Hillebrand, Claudia and Hughes, R. Gerald. "The Quest for a Theory of Intelligence." In The Palgrave Handbook of Security, Risk and Intelligence, edited by Robert Dover, Huw Dylan and Michael Goodman, 1-24. Basingstoke: Palgrave, 2017.

Howard, M. The Lessons of History. Oxford: Oxford University Press, 1991.

Howard, M. Clausewitz: A Very Short Introduction. Oxford: Oxford University Press, 2002.

Hoyt, T. D. "Clausewitz and Small Wars: The Conceptual Origins of the 'Remarkable Trinity." Journal of Strategic Studies 40/3 (2017): 438-442. doi:10.1080/01402390.2016.1270804.

Hughes, R. Gerald. "Strategists and Intelligence." In Routledge Companion to Intelligence Studies edited by Rob Dover, Michael Goodman and Claudia Hillebrand, 50-58. London and New York: Taylor \& Francis, 2014.

Hughes, R. Gerald. "War as Political Violence." In The Ashgate Research Companion to Political Violence edited by Marie Breen-Smyth, 347-366. Farnham: Ashgate, 2017.

Ignatius, D. "From the Viet Cong to the Islamic State, the Perils of Underestimating the Enemy's 'Will'." Washington Post, September 22, 2014.

Jervis, R. "The Politics and Psychology of Intelligence and Intelligence Reform." The Forum 4/1 (2006): 1-9.

Jervis, R. Why Intelligence Fails: Lessons from the Iranian Revolution and the Iraq War. Ithaca, NY: Cornell University Press, 2010.

Jervis, R. "Response by Robert Jervis to H-Diplo Roundtable Review of Jervis, Why Intelligence Fails, H-Diplo Roundtable Review, Volume XI/32." 9 July 2010. Accessed September 4, 2017. www.h-net.org/ diplo/roundtables

Johnson, L. K. National Security Intelligence: Secret Operations in Defense of the Democracies. 2nd rev ed. Cambridge: Polity, 2017.

Kahn, D. "Clausewitz and Intelligence." Journal of Strategic Studies 9(2-3) (1986): 117-126. doi:10.1080/ 01402398608437261.

Kaldor, M. "Inconclusive Wars: Is Clausewitz Still Relevant in These Global Times?" Global Policy 1/3 (2010): $271-281$. doi:10.1111/j.1758-5899.2010.00041.x.

Kaldor, M. New \& Old Wars: Organized Violence in a Global Era. 3rd ed. Stanford, CA: Stanford University Press, 2012.

Kant, I., and T. Humphrey, (trans.). Perpetual Peace and Other Essays on Politics, History, and Morals: A Philosophical Essay. New York: Hackett, 1983.

Keegan, J. A History of Warfare. London: Hutchinson, 1993.

Kitfield, J. 2016. "How Mike Flynn Became America's Angriest General." Politico, October 16. Accessed July 14, 2017 http://www.politico.com/magazine/story/2016/10/how-mike-flynn-becameamericas-angriest-general-214362

Koutsoukis, A. "Building an Empire or Not? Athenian Imperialism and the United States in the Twenty-First Century." Global Discourse 3/1 (2013): 12-30. doi:10.1080/23269995.2013.808847.

Koutsoukis, A. "Challenging Victor Bias and Status Quo Bias in Realist Accounts of Surrender: Re-Reading Three Cases of Surrender from the Peloponnesian War." Unpublished PhD Thesis, Aberystwyth University, 2016.

Levy, J. S. "Clausewitz and People's War." Journal of Strategic Studies 40/3 (2017): 450-456. doi:10.1080/ 01402390.2016.1270805.

Luvaas, J. "Clausewitz, Fuller and Liddell Hart." Journal of Strategic Studies 9, no. 2-3 (1986): 197-212. doi:10.1080/ 01402398608437266.

Luvaas, J. "Napoleon's Use of Intelligence: The Jena Campaign of 1805." Intelligence and National Security 3/3 (2008): $40-54$.

Machiavelli, N. The Art of War. Revised Edition of the Ellis Farneworth translation, with an Introduction by Neal Wood. New York: Da Capo, 2001 [1521].

McCabe, D. "Hegel and the Idea of Philosophical History." History of Philosophy Quarterly 15/3 (1998): 369-388.

Meilinger, P. S. "China and Clausewitz." Defense Analysis 17/3 (2001): 325-326. doi:10.1080/07430170152627708.

Moran, K. A., ed. Kant on Freedom and Spontaneity. Cambridge: Cambridge University Press, 2018.

Morgenthau, H. J. Politics among Nations: The Struggle for Power and Peace. 2nd ed. New York: Alfred A. Knopf, 1954.

Papish, L. Kant on Evil, Self-Deception, and Moral Reform. New York: Oxford University Press USA, 2018. 
Paret, P. "Clausewitz." In Makers of Modern Strategy: From Machiavelli to the Nuclear Age, edited by P. Paret, 186-213. Princeton, NJ: Princeton University Press, 1986.

Paret, P. Clausewitz in His Time: Essays in the Cultural and Intellectual History of Thinking about War. Oxford: Berghahn, 2015.

Prados, J., and C. Ames. "THE IRAQ WAR - PART II: Was There Even a Decision? U.S. And British Documents Give No Indication Alternatives Were Seriously Considered", National Security Archive Electronic Briefing Book No. 328. 2018. Accessed February 16, 2018. https://nsarchive2.gwu.edu/NSAEBB/NSAEBB328/index.htm

Schama, S. Citizens: A Chronicle of the French Revolution. New York: Random House, 1989.

Schelling, T. C. The Strategy of Conflict. Cambridge, MA: Harvard University Press, 1960.

Schelling, T. C. Arms and Influence. New Haven, CT: Yale University Press, 1966.

Schelling, T. C., and M. H. Halperin. Strategy and Arms Control. New York: The Twentieth Century Fund, 1961.

Shepherd, M. F. L., III. The Fog of War: Effects of Uncertainty on Airpower Employment. New York, NY: PN Books, 1997.

Shy, John. "Jomini." In Makers of Modern Strategy: From Machiavelli to the Nuclear Age, edited by P. Paret, 143-185. Oxford: Clarendon Press, 1986.

Siddiqui, Sabrina (Washington DC). "Mike Flynn Indicates He Would Testify in Trump-Russia Inquiry in Exchange for Immunity." The Guardian, March 31, 2017. London. Accessed August 8, 2017. https://www.theguardian.com/usnews/2017/mar/30/michael-flynn-trump-russia-investigation-testify-immunity

Souchon, L. Carl von Clausewitz und Strategie im 21. Jahrhundert. Hamburg: Mittler \& Sohn Verlag, 2012.

Tiejun, Y. "The Western Master and Bible of War: Clausewitz and His "On War" in China'." In Clausewitz Goes Global: Carl Von Clausewitz in the 21st Century, edited by R. Pommerin, 42-59. Berlin: Miles-Verlag, 2014.

Urban, M. The Man Who Broke Napoleon's Codes: The Story of George Scovell. London: Faber \& Faber, 2001.

Van Creveld, M. On Future War. London: Brassey's, 1991.

Van Puyvelde, D., S. Coulthart, and H. M. Shahriar. "Beyond the Buzzword: Big Data and National Security Decision-Making." International Affairs 93/6 (2017): 1397-1416. doi:10.1093/ia/iix184.

Voltaire (François-Marie Arouet). The History of Charles XII, King of Sweden. Translated by Antonia White. Edited by R. M. Hatton. London: Folio Society, 1976 [1731].

Waldman, T. War, Clausewitz and the Trinity. Farnham: Ashgate, 2013.

Wilson, S., and M. D. Shear "Obama Relieves McChrystal of His Duties: Names Petraeus as Replacement." The Washington Post, June 23, 2010.

Wolf, J. 'CIA Inquest Finds US Missed Indian 'Mindset'.' UPI wire service, June 3, 1998.

Wolfberg, A. "The President's Daily Brief: Managing the Relationship between Intelligence and the Policymaker." Political Studies Quarterly 132/2 (2017): 225-258.

Zedong, M. Six Essays on Military Affairs. Peking: Foreign Languages Press, 1972.

Zeller, M. Watches without Time: An American Soldier in Afghanistan. Charlottesville, VA: Just World Books, 2012. 